\title{
Discussion: Use of adiabatic calorimetry for performance assessment of concretes
}

\section{Y. K. Ramu}

Department of Civil Engineering, IIT Madras, Chennai, India I. Akhtar

Department of Civil Engineering, IIT Madras, Chennai, India M. Santhanam

Department of Civil Engineering, IIT Madras, Chennai, India

A. K. H. Kwan

Department of Civil Engineering, The University of Hong Kong,

Pokfulam, Hong Kong

\section{P. L. Ng}

Department of Civil Engineering, The University of Hong Kong, Pokfulam, Hong Kong; Faculty of Civil Engineering, Vilnius Gediminas Technical University, Vilnius, Lithuania

\section{Contribution by A. K. H. Kwan and P. L. Ng}

The authors have produced some useful experimental data on the heat evolution of concrete mixes containing different mineral admixtures (Ramu et al., 2016). These data may be further analysed for deeper study.

For the ordinary Portland cement (OPC) concrete, it is observed that the heat evolution was not directly proportional to the cement content, as listed in Table 6, where it can be seen that the total heat varied from $245 \mathrm{~kJ} / \mathrm{kg}$ at a water to cement $(w / c)$ ratio of 0.38 to $256 \mathrm{~kJ} / \mathrm{kg}$ at a $w / c$ ratio of 0.45 . Such variation may be attributed to the incomplete degree of hydration, which is dependent on the $w / c$ ratio, as has been found in previous studies by the discussers ( $\mathrm{Ng}$ et al., 2008, 2009).

For the fly ash concrete, it is evident from the results listed in Table 7 that the total heat was generally lower at a higher fly ash replacement ratio and/or a lower water to binder $(w / b)$ ratio. Again, the lower total heat at lower $w / b$ ratio and higher total heat at higher $w / b$ ratio may be attributed to the difference in degree of chemical reactions at different $w / b$ ratios, as has been reported previously by the discussers (Kwan et al., 2011a). The placing temperature might have also affected the total heat, but the placing temperature results have not been given in the paper.

For the silica fume concrete, for which the results are summarised in Table 8 , it is particularly interesting to note that the addition of $5 \%$ silica fume has reduced the total heat by $8.0 \%$, whereas the addition of $10 \%$ silica fume has reduced the total heat by $10 \cdot 3 \%$. Hence, the percentage reduction in heat evolution was larger than the percentage reduction in cement content. A similar phenomenon was observed by the discussers in a previous study (Kwan et al., 2011b). Further research is recommended to explain this phenomenon.

\section{Authors' reply}

The authors thank Dr Kwan and Dr Ng for their insightful discussion of this paper. Indeed, the extent of the chemical

$\begin{array}{ccccc}\text { Mix } & \begin{array}{c}\text { Water } \\ \text { content: } \mathrm{kg} / \mathrm{m}^{3}\end{array} & \begin{array}{c}\text { Cement } \\ \text { content: } \mathrm{kg} / \mathrm{m}^{3}\end{array} & \text { ratio } & \text { rat } \\ & \text { heat: } \mathrm{kJ} / \mathrm{kg}\end{array}$

\begin{tabular}{lllll}
\hline C2-M30-1 & 171 & 380 & $0 \cdot 45$ & 256 \\
C2-M30-6 & 153 & 360 & $0 \cdot 43$ & 250 \\
C2-M50-3 & 180 & 470 & $0 \cdot 38$ & 245
\end{tabular}

Table 6. Total heat evolution of OPC concrete

\begin{tabular}{lcccc}
\hline Mix & $\begin{array}{c}\text { Fly ash } \\
\text { replacement } \\
\text { ratio }\end{array}$ & $\begin{array}{c}\text { Binder } \\
\text { content: } \\
\mathrm{kg} / \mathrm{m}^{3}\end{array}$ & $\begin{array}{c}\mathrm{w} / \mathrm{b} \\
\text { ratio }\end{array}$ & $\begin{array}{c}\text { Total } \\
\text { heat: } \\
\mathrm{kJ} / \mathrm{kg}\end{array}$ \\
\hline C2-M30-2 & 0.25 & 400 & 0.45 & 274 \\
C2-M30-3 & 0.21 & 380 & 0.43 & 277 \\
C2-M30-4 & 0.38 & 450 & 0.39 & 219 \\
C2-M30-5 & 0.25 & 480 & 0.47 & 207 \\
C2-M30-7 & 0.17 & 360 & 0.50 & 377 \\
C2-M30-8 & 0.29 & 450 & 0.42 & 190 \\
C2-M30-9 & 0.27 & 460 & 0.49 & 226
\end{tabular}

Table 7. Total heat evolution of fly ash concrete

\begin{tabular}{lcccc}
\hline Mix & $\begin{array}{c}\text { Silica fume } \\
\text { replacement } \\
\text { ratio }\end{array}$ & $\begin{array}{c}\text { Binder } \\
\text { content: } \\
\mathrm{kg} / \mathrm{m}^{3}\end{array}$ & $\begin{array}{c}\text { W/b } \\
\text { ratio }\end{array}$ & $\begin{array}{c}\text { Total } \\
\text { heat: } \\
\mathrm{kJ} / \mathrm{kg}\end{array}$ \\
\hline C1-M80-P & 0 & 430 & 0.35 & 261 \\
C1-M80-MA1 & 0.05 & 430 & 0.35 & 240 \\
C1-M80-MA2 & 0.10 & 430 & 0.35 & 234
\end{tabular}

Table 8. Total heat evolution of silica fume concrete 
reactions at different $w / b$ ratios is expected to have an effect on the heat evolved. However, the authors wish to clarify that this was not a parametric study; rather, they analysed only heat evolution from concretes with mixture designs that are used commercially. Further, as rightly pointed out, additional work is necessary to understand the reduction in heat evolution with silica fume concrete, particularly also considering the influence of the particle size of the material.

\section{REFERENCES}

Kwan AKH, Fung WWS, Chen JJ and Ng PL (2011a) Heat generation of curing fly ash concrete at different $w / \mathrm{cm}$. ACI Materials Journal 108(3): 307-315.
Kwan AKH, Chen JJ, Fung WWS and Ng PL (2011b) Effects of silica fume on heat generation of curing concrete. $A C I$ Materials Journal 108(6): 655-663.

$\mathrm{Ng} \mathrm{PL}, \mathrm{Ng}$ IYT and Kwan AKH (2008) Heat loss compensation in semi-adiabatic curing test of concrete. ACI Materials Journal 105(1): 52-61.

$\mathrm{Ng}$ IYT, Ng PL and Kwan AKH (2009) Effects of cement and water contents on adiabatic temperature rise of concrete. ACI Materials Journal 106(1): 42-49.

Ramu YK, Akhtar I and Santhanam M (2016) Use of adiabatic calorimetry for performance assessment of concretes. Advances in Cement Research 28(8): 485-493, http://dx.doi. org/10.1680/jadcr.15.00097. 